\title{
PERAN NASABAH DALAM PERKEMBANGAN PERBANKAN SYARIAH
}

\author{
Intan Manggala Wijayanti \\ Fakultas Syariah Universitas Islam Bandung \\ Jl. Ranggagading No. 8 Bandung \\ intanmanggala267@gmail.com
}

\begin{abstract}
Abstrak : Perbankan syariah memerlukan berbagai upaya dalam mencapai target market share sebesar 20\% dalam kurun waktu lima tahun kedepan, dimana tahun 2018 market share baru mencapai $5,44 \%$. Tentunya upaya melalui berbagai program maupun proses pemasaran harus terancang dengan baik. Saat ini dana murah yang dikelola lembaga perbankan syariah proporsinya hanya 8 persen, selebihnya merupakan dana mahal. Hal ini memaksa perbankan dalam mengeluarkan dana lebih besar untuk pembayaran nisbah bagi hasil kepada nasabah. Penelitian ini bertujuan untuk menjelaskan peluang-peluang yang dapat dilakukan oleh nasabah dalam berkontribusi untuk mengembangkan perbankan syariah di Indonesia. Penelitian ini menggunakan metode deskriptif analisis dengan sumber data sekunder yang diambil dari hasil olahan OJK. Hasil dari penelitian ini, di antaranya bahwa perkembangan perbankan syariah di Indonesia perlu banyak dukungan dari berbagai pihak dan aspek, seperti dukungan pemerintah, beragam inovasi dalam pengembangan produk yang dibutuhkan di masyarakat, dan dukungan dari para nasabah sendiri, seperti dalam keputusan berinvestasi di bank syariah, dengan harapan ke depannya perbankan syariah dapat bersaing tidak hanya dalam pengembangan aset, namun juga pada market share.
\end{abstract}

Kata Kunci: nasabah, perbankan syariah, market share

Abstract : Sharia banking need various efforts to achieve the target of market share of about 20 percent in the past five years, where in the year 2018 market share has only reached 5.44 $\%$. Of course efforts through various of the program and the process of marketing have to be in designed well. Now low funding costs maintained in banking institutions sharia the proportion only 8 percent, the remainder are expensive funds, it forces banking the issuing of savings in in payment of the ratio of the for the to customers. This study attempts to explain the opportunities that can be done by customers in contributing to develop sharia banks in Indonesia. This research using methods descriptive analysis by secondary data taken from processing the Otoritas Jasa Keuangan. The result of this research, of them that of the Sharia banks in Indonesia needs to a great deal of support from various parties and aspects, such as support the government, innovation in product development required at the community, and support of our clients own, as in the decision invest in sharia banks, in the hope of sharia banking in the future can compete not only in the development of assets, but also back market share.

Keynote: customer, sharia bank, market share

\section{PENDAHULUAN}

Perbankan syariah merupakan lembaga yang beberapa tahun terakhir menjadi fokus dalam kegiatan perekonomian di Indonesia, tidak hanya perkembangan dari segi bertambahnya

Received: 2018-11-14 | Reviced: 2019-01-24 | Accepted: 2019-02-07

Indexed : DOAJ, Garuda, Crossref, Google Scholar | DOI : https://doi.org/10.29313/amwaluna.v3i1.4195 
Unit Usaha Syariah yang sudah bertranformasi menjadi Bank Umum Syariah, namun perkembangan asset keuangan perbankan, pasar modal dan IKNB. Menurut Otoritas Jasa Keuangan dalam Siaran Persmengenai Market Share Keuangan Syariah di Gelaran Keuangan Syariah Fair di Cibinong Bogor diungkapkan bahwa saat ini hingga Agustus 2017 total asset keuangan syariah Indonesia (tidak termasuk saham syariah) mencapai Rp. 1.048,8 triliun, adapun data market Share perbankan syariah masih menduduki di angka 5,44\%.

Namun masih banyak permasalahan yang saat ini terus dihadapi oleh perbankan syariah di Indonesia. Market share perbankan syariah yang memiliki target sebesar $20 \%$ dalam kurun waktu lima tahun kedepan tentunya harus memilki banyak upaya dan strategi yang harus dibuat dalam rangka pencapaian target tersebut. Selain industry perbankan itu sendiri yang harus melakukan upayaupaya pengem-bangan seperti pengembangan inovasi produk, service excellent dan pengembangan teknologi, masya-rakat itu sendiri juga harus memiliki upaya dalam rangka membantu perkembangan perbankan syariah, terutama nasabah bank syariah itu sendiri.

Tabel 1

Aset dan Market Share Industri Keuangan Syariah

\begin{tabular}{|l|r|r|r|}
\hline \multirow{2}{*}{ Industri } & \multicolumn{2}{|c|}{ Total aset dalm triliun } & \multirow{2}{*}{$\begin{array}{c}\text { Market Share } \\
\text { \% }\end{array}$} \\
\cline { 2 - 4 } & $\begin{array}{r}\text { Total aset konvensional } \\
\text { Dan syariah }\end{array}$ & $\begin{array}{c}\text { Total aset } \\
\text { syariah }\end{array}$ \\
\hline Perbankan & $7.158,40$ & 389,74 & $5,44 \%$ \\
\hline IKNB & $2.073,43$ & 99,15 & $4,78 \%$ \\
\hline Pasar Modal & $3.861,09$ & 559,59 & $14,49 \%$ \\
\hline TOTAL & $\mathbf{1 3 . 0 9 2 , 9 1}$ & $\mathbf{1 . 0 4 8 , 4 8}$ & $\mathbf{8 , 0 9 \%}$ \\
\hline
\end{tabular}

Sumber : SP 102/DHMS/OJK/X/2017

Nasabah merupakan asset berharga yang dimiliki oleh sebuah bank (ROSANA, 2009), dimana nasabah merupakan nadi dari kegiatan perbankan, namun sejauh mana nasabah memiliki kontribusi terhadap perkembangan perbankan syariah. Secara umum nasabah dapat dibagi menjadi beberapa tipe nasabah, nasabah dengan loyalitas tinggi dan nasabah dengan kontribusi minimalis yang dimaksud dengan nasabah loyaltas tinggi adalah nasabah dengan peran 
sangat menggantungkan diri terhadap bank yang dipilih sebagai tempat intermediasi, biasanya nasabah tersebut merupakan nasabah dengan tingkat aktifitas perbankan yang cukup tinggi meliputi penempatan dana simpanannya di bank tersebut, memanfaatkan segala fasillitas perbankan tambahan bahkan menjadi nasabah pembiayaan di bank tersebut. Namun berbeda hal dengan nasabah dengan kontribusi yang minimalis yang biasanya sekedar menjadi nasabah dibank tersebut, sebagai contoh nasabah dengan latar belakang system payroll yang mengharuskan atau mau tidak mau nasabah tersebut menjadi nasabah dibank tersebut.

Jika melihat 2 tipe nasabah diatas, tentu saja nasabah dengan loyalitas tinggi yang sangat diharapkan oleh bank syariah selain dapat memberikan gairah transaksi yang masih minim, banyak harapanharapan lain yang ingin di bagikan kepada nasabah tersebut. Ada beberapa hal yang dapat dilakukan oleh nasabah untuk membantu perkembangan bank syariah di Indonesia, sebuah aksi kecil dimana dengan aksi tersebut dapat memberikan kontribusi yang besar terhadap perbankan syariah. Sehingga harapan besar dengan berkontribusinya nasabah terhadap perbankan syariah maka dapat membantu perbankan syariah berkembang menuju kearah yang lebih baik.

\section{Tujuan dan Manfaat}

Tujuan yang ingin dicapai adalah untuk menjelaskan peluang-peluang yang dapat dilakukan oleh nasabah dalam berkontribusi untuk mengembangkan perbankan syariah di Indonesia. Adapun manfaat yang ingin dicapai adalah (1) memperkaya referensi tentang kajian perbankan syariah di Indonesia (2) secara praktis, memberikan masukan atau ide pemikiran kepada praktisi di lingkungan perbankan Syariah dan akademisi serta para nasabah perbankan syariah.

\section{Metode Penelitian}

Penelitian ini menggunakan metode deskriptif analisis, di mana peneliti mengambil data berupa hasil olahan dari OJK yang ditujukan pada Bank Umum Syariah. Meskipun data yang digunakan meurpakan data sekunder, namun penelitian ini diharapkan dapat memberikan gambaran dan masukan berkaitan peran nasabah dalam upaya mendukung perkembangan bank syariah di Indonesia.

\section{PEMBAHASAN}

\section{Nasabah Perbankan Syariah}

Menurut Undang undang Republik Indonesia Nomor 21 tahun 2008 tentang perbankan syariah, nasabah adalah pihak yang menggunakan jasa bank syariah dan 
atau unit usaha syariah (Widayu, Nasution,

Silalahi, \& Mesran, 2017). Nasabah dalam

UU nomor 21 tahun 2008 terbagi menjadi

3 jenis nasabah sebagai berikut :

1. Nasabah Penyimpan adalah nasabah yang menempatkan dananya di Bank Syariah dan / atau Unit usaha syariah dalam bentuk simpanan berdasarkan akad antara bank syariah atau UUS dan nasabah yang bersangkutan sedangkan;

2. Nasabah Investor nasabah yang menempatkan dananya di Bank Syariah dan / atau Unit usaha syariah dalam bentuk Investasi berdasarkan akad antara bank syariah atau UUS dan nasabah yang bersangkutan, dan

3. Nasabah penerima fasilitas adalah nasabah yang memperoleh fasilitas dana atau yang dipersamakan dengan itu, berdasarkan prinsip syariah.

Menurut data Otoritas Jasa Keuangan perkembangan nasabah bank syariah cukup memuaskan setiap tahunnya, berikut perkem-bangan nasabah perbankan syariah di Indonesia pada tahun 2014-2017

Tabel 2.

Tabel Perkembangan Jumlah Nasabah

\begin{tabular}{|l|c|r|r|r|}
\hline \multicolumn{1}{|c|}{ TIPE } & \multicolumn{4}{|c|}{ JUMLAH NASABAH } \\
\cline { 2 - 5 } & $\mathbf{2 0 1 4}$ & $\mathbf{2 0 1 5}$ & $\mathbf{2 0 1 6}$ & \multicolumn{1}{c|}{$\mathbf{2 0 1 7}$} \\
\hline Dana Pihak Ketiga & 11.444 .013 & 14.761 .002 & 18.521 .091 & 21.692 .463 \\
\hline $\begin{array}{l}\text { Pembiayaan, Piutang } \\
\text { dan Salam }\end{array}$ & 3.175 .910 & 3.401 .887 & 3.801 .121 & 4.520 .667 \\
\hline Total & 14.619 .923 & 18.162 .889 & 22.322 .212 & 26.213 .130 \\
\hline
\end{tabular}

Sumber : SPS OJK Agustus 2018 (Data Diolah)

Dari table 2 di atas dapat diketahui bahwa nasabah perbankan syariah mengalami peningkatan yang cukup baik dari tahun ke tahun. Perkembangan porsentase jumlah nasabah perbankan syariah di tahun 2014 meningkat sebanyak $24,23 \%$ ditahun 2015. Sedangkan jumlah nasabah dari tahun 2015 meningkat
22,90\% dan menuju tahun 2017 hanya mengalami peningkatan $17,43 \%$ dari tahun 2016. Meskipun terlihat bahwa peningkatan jumlah nasabah cukup baik ada baiknya peningkatan jumlah nasabah di perbankan syariah perlu ditingkatkan kembali dari tahun ketahun minimal setiap tahun peningkatan tersebut mencapai 
angka yang lebih baik dari tahun sebelumnya.

Melihat potensi jumlah nasabah perbankan syariah yang cukup besar, adakalanya tidak hanya perbankan syariah dan pemerintah sebagai pihak yang bertanggung jawab atas perkembangan perbankan syariah namun nasabah juga berperan penting terhadap perkembangan bank syariah dalam hal ini upaya memperluas market share yang ada di Indonesia.

\section{Peran Nasabah dalam Perkembangan Bank Syariah}

Bank sebagai lembaga intermediasi memiliki tugas untuk mengumpulkan dana dari masyarakat sehingga proses penyaluran dana kepada masyarakat untuk menggerakan perekonomian dapat terlaksana dengan baik. Seluruh dana yang berada di perbankan tentunya sebagian besar berasal dari dana yang dimilki masyarakat termasuk didalam nya dana milik pemerintah dana perusahaan dari berbagai sector. Upaya upaya tentu akan dilakukan perbankan dengan berbagai program dan strategi yang dimilki dalam mencapai target dana yang harus dicapai oleh sebuah bank. Target dana pihak ketiga yang menjadi sumber utama dalam kegiatan perbankan menjadi tugas yang cukup berat mengingat persaingan antar perbankan syariah saat ini sudah tidak dapat dikatakan sebagai pasaar yang luas.

Berbagai upaya yang perlu dilakukan oleh bank dalam menarik minat masyarakat untuk menyimpan dananya dibank, salah satu nya adalah memberikan penawaran menarik atas nisbah bagi hasil yang akan diberikan kepada nasabah. Menurut Evi Natalia dalam jurnal Pengaruh Tingkat Bagi Hasil Deposito Bank Syariah dan Suku Bunga Deposito Bank Umum terhadap jumlah simpanan deposito, bahwa variable tingkat bagi hasil berpengaruh secara siginifikan terhadap Jumlah simpanan Deposito Mudharabah. Sedangkan menurut Prasetya (2015) dalam penelitiannya dikatakan bahwa Suku Bunga, Equivalent Rate, Pertumbuhan Ekonomi dan Pertumbuhan Outlet secara bersama sama berpengaruh secara nyata terhadap DPK Perbankan syariah.

Dari hasil penelitian tersebut diatas, dapat dilihat bahwa salah satu faktor yang dapat menarik nasabah untuk menyimpan dananya di bank syariah adalah tingkat bagi hasil. Dilapangan sering terjadi bahwa kondisi bank syariah memiliki kebutuhan akan peningkatan dana pihak ketiga, hal tersebut mengharuskan bank bergerak mencari dana dengan jumlah yang cukup tinggi pada rentan waktu tertentu, hal ini dapat mengakibatkan lemahnya bargaining power yang dimiliki 
oleh bank syariah dalam bentuk penawaran penyimpanan deposito dengan special nisbah bagi hasil. Special nisbah bagi hasil adalah nisbah dengan tingkat yang lebih tinggi dibandingkan dengan nisbah yang ditentukan oleh bank secara umum.

Begitu pula sebaliknya, saat nasabah memilki dana yang cukup fantastis nasabah akan melakukan negosiasi dan permohonan untuk mendapatkan special nisbah. Jika permohonan dan penawaran tersebut di setujui, salah satu dampak yang paling nyata terlihat adalah keharusan bank membayar lebih bagi hasil yang mengakibatkan besarnya biaya bagi hasil yang harus dikeluarkan oleh bank yang dapat disebut sebagai biaya dana.

Menurut Kasmir, biaya dana atau cost of fund adalah total biaya bunga yang dikeluarkan oleh bank untuk setiap dana yang dihimpunnya dalam berbagai sumbe rsebelum dikurangi dengan likuiditas wajib.

Biaya dana dapat terbagi menjadi 2 jenis yaitu dana murah dan dana mahal.Dana mahal adalah bank membayarkan atau memberikan bunga atau bagi hasil atas sejumlah dana yang disimpan lebih tinggi dibandingkan dengan produk berdana murah, dalam hal ini produk dengan dana mahal adalah deposito.

Dana murah adalah sejumlah bunga atau bagi hasil yang diberikan kepada nasabah atas sejumlah dana yang disimpan di bank namun dengan tingkat bagi hasil yang rendah dimana dalam hal ini Dana Murah sering diartikan sebagai penyimpanan dana pihak ketiga di produk tabungan dan giro yang tentunya memiliki tingkat bagi hasi yang lebih rendah dari produk deposito.

Menurut Rini (2016) dalam tulisannya mengenai biaya dana bahwa tantangan bank syariah di era bunga murah dikatakan bahwa dana murah yang dikelola dilembaga perbankan syariah proporsinya hanya 8 persen, selebihnya merupakan dana mahal. Dari jenis simpanannya, simpanan deposito merupakan sumber dana pihak ketiga yang paling dominan dilembaga perbankan syariah yakni mencapai $61,13 \%$. Dengan cukup siginifikannya beban biaya dana menjadikan laba industri perbankan syariah mengalami penurunan $9.54 \%$ dari tahun 2015.

Berikut merupakan table equivalent rate atas tingkat imbalan/ bagi hasil/ fee/ bonus dari produk dana pihak ketiga: 
Tabel 3

Tabel Equivalent Rate Tingkat Imbalan/ Bagi Hasil Dana Pihak Ketiga

\begin{tabular}{|l|c|r|r|r|}
\hline \multicolumn{1}{|c|}{ INDIKATOR } & $\mathbf{2 0 1 4}$ & $\mathbf{2 0 1 5}$ & $\mathbf{2 0 1 6}$ & $\mathbf{2 0 1 7}$ \\
\hline I. Dana Pihak Ketiga & 6.72 & 5.88 & 4.76 & 4.61 \\
\hline 1. Giro iB Wadiah & 1.25 & 1.18 & 1.53 & 1.46 \\
\hline 2. Tabungan iB Wadiah & 4.81 & 4.33 & 2.58 & 1.70 \\
\hline 3. Giro iB Mudharabah & 1.58 & 2.89 & 2.43 & 2.38 \\
\hline 4. Tabungan iB Mudharabah & 4.37 & 3.59 & 2.44 & 2.42 \\
\hline 5. Deposito iB Mudharabah & 8.06 & 7.17 & 6.04 & 5.85 \\
\hline
\end{tabular}

Sumber : SPS OJK Agustus 2018 (Data Diolah)

Tabel 4

Tabel Dana Pihak Ketiga Perbankan Syariah

\begin{tabular}{|c|c|c|c|c|c|}
\hline \multicolumn{2}{|r|}{ INDIKATOR } & 2014 & 2015 & 2016 & 2017 \\
\hline \multirow{3}{*}{1} & Dana Simpanan Wadiah & 29,073 & 32,532 & 38,361 & 47,033 \\
\hline & a. Giro & 16,512 & 17,327 & 20,153 & 24,897 \\
\hline & b. Tabungan & 12,561 & 15,206 & 18,208 & 22,137 \\
\hline \multirow{4}{*}{2} & $\begin{array}{l}\text { Dana Investasi Non Profit } \\
\text { Sharing }\end{array}$ & 187,638 & 197,475 & 240,974 & 287,854 \\
\hline & a. Giro & 2,132 & 3,859 & 7,820 & 5,291 \\
\hline & b. Tabungan & 50,949 & 53,388 & 66,980 & 76,361 \\
\hline & c. Deposito & 134,556 & 140,228 & 166,174 & 196,202 \\
\hline
\end{tabular}

Sumber : SPS OJK Agustus 2018 (Data Diolah)

Dari table tersebut dapatdilihat namun dapat dilihat juga di table equivalent rate atas produk dengan dana Equivalent Rate (tabel 3) bahwa saat ini murah berada di kisaran $1 \%$ hingga $4 \%$ komposisi dana pihak ketiga masih 
didominasi oleh produk deposito yang tentunya memiliki nisbah bagi hasil atau equivalent rate lebih tinggi dibanding dengan tabungan. Dengan adanya penerapan dana mahal yang di bank, hal tersebut berpengaruh lansgung terhadap penetapan margin atas produk pembiayaan.

Margin adalah kenaikan bersih dari asset bersih sebagai akibat dari memegang asset yang mengalami peningkatan nilai selama periode yang dipilih oleh peryataan pendapatan. Keuntungan juga dapat diperoleh dari pemindahan saling tergantung incidental yang sah dan yang tidak saling tergantung, kecuali transfer yang tidak saling tergantung dengan pemegang saham, atau pemegangpemegang rekening investasi tak terbatas dan yang setara dengannya. (Sri dewi anggadini, Penerapan margin pembiayaan murabahah pada BMT As-Salam, Majalah Ilmiah UNIKOM, Vol 9, No. 2. H.190)

Dari definisi tersebut margin dapat didefinisikan sebagai selisih dari asset yang mengalami peningkatan atau kenaikan nilai.Margin keuntungan ditetapkan dalam rapat dalam perbankan yang disebut sebagai rapat Asset/Liability Management Committee (ALCO) Bank Syariah, dalam rapat tersebut sebagai anggota rapat adalah tim yang berkompeten dan berkepentingn dalam penetuan nilai margin yaitu Direktur Utama, Divisi Keuangan, Divisi Akuntansi, Divisi Pembiayaan, Divisi Dana, dan Divisi kebijakan.

Penetapan margin keuntungan menurut Adiwarman Karim, disebutkan bahwa ada beberapa pertimbangan Tim ALCO dalam menetapkan nilai margin sebagai berikut:

a. Direct Competitor's Market (DCMR)

b. Indirect Competitor's Market Rate (ICMR)

c. Expected Competitive Return Investors (ECRI)

d. Acquiring Cost

e. Overhead Cost

Beberapa faktor lain yang perlu ditetapkan dalam penetapan margin dan bagi hasil antara lain slah satu nya adalah Komposisi pendanaan (manajemen dana bank syariah), dimana Bagi bank syariah yang pendanaannya sebagian besar diperoleh dari dana giro dan tabungan dimana dana tersebut tidak memerlukan pembagian bagi hasil yang besar, maka margin yang ditentukan akan memiliki nilai yang lebih kompetitif dibandingkan dengan bank dengan porsi deposito lebih besar daripada giro dan tabungan.

Kondisi yang terjadi saat perbankan memiliki banyak komposisi dana mahal maka tentu akan berakibat langsung 
terhadap harga jual margin yang cukup tinggi. Hal ini akan dilakukan guna hasil penjualan pembiayaan yang didapat digunakan untuk menutupi biaya dana bagi hasil.

Jika melihat kondisi diatas, maka dapat diketahui beberapa peluang yang dapat dilirik bagi perkembangan perbankan syariah, di antaranya dalam melakukan proses negosiasi saat bertransaksi bagi hasil deposito misalnya, yang secara tidak langsung akan memengaruhi nilai margin yang ditawarkan. Walaupun di sisi lain saat ini tingginya nilai margin yang ditawarkan kepada calon nasabah lain tentunya dapat menjadi tidak kompetitif, dan kemunculan ketidak kompetitifan berpengaruh terhadap melambatnya pertumbuhan market share perbankan syariah. Selain itu bentuk kepercayaan nasabah yang masih rendah terhadap performa bank syariah menjadi salah satu alasan calon nasabah dan nasabah masih melakukan negosiasi atas bagi hasil deposito karena nasabah masih beranggapan bahwa performa bank syariah belum dapat menyamai kinerja bank konvensial dan ini merupakan tugas bersama sebagai masyarakat perbankan syariah untuk memupuk kepercayaan tersebut.

\section{SIMPULAN}

Perbankan syariah yang saat ini masih berusaha dalam pencapaian target Market share tentunya membutuhkan dukungan dari banyak pihak, seperti campur tangan dukungan pemerintah, inovasi dalam pengembangan produk yang dibutuhkan masyarakat dan pihak ketiga, serta tak lain dukungan dari nasabah bank syariah itu sendiri. Nasabah memiliki posisi yang strategis dalam perbankan syariah, posisi yang tentu memberikan keuntungan bagi bank ataupun posisi yang memberikan tambahan beban bagi bank itu sendiri. Nasabah tak lain adalah masyarakat pereko-nomian yang sebetulnya memegang andil dalam upaya perkembangan bank syariah. Oleh karena itu diharapkan masyarakat juga memiliki kesadaran dalam perkembangan bank syariah, dimulai dengan memberikan dukungan dalam keputusan berinvestasi. Keputusan berinvestasi melalui produk simpanan di bank syariah tentunya merupakan langkah yang tepat dilakukan, namun nasabah itu sendiri perlu meningkatkan kepercayaan atas performa dari bank atas pengelolaan dana simpanan tersebut dimulai dari meminimalisasi proses negosiasi nisbah bagi hasil atas simpanan tersebut. Hal ini tentu dapat meminimalisir bank mengeluarkan dana bagi hasil yang cukup besar yang tentunya sangat memberikan dampak juga terhadap 
penetapan margin pembiayaan. Penetapan margin yang "overprice" menjadikan bank syariah tidak dapat ikut bersaing dalam kegiatan pemasaran produk dan tentunya dapat menghambat bank syariah berkembang dengan baik dari sisipengembangan asset maupun market share.

\section{Daftar Pustaka}

Anggadini, S. D. (n.d.). Penerapan Margin Pembiayaan Murabahah pada BMT As-Salam Pacet-Cianjur. Majalah Ilmiah UNIKOM, 9(1), pp. 187198.

Annisa Sulistyo Rini, I. F. (2016, Maret 04). syariahbukopin.co.id.

Retrieved Oktober 28, 2018, from syariahbukopin.co.id.

Karim, A. (2007). Bank Islam (Analisis Fiqih dan Keuangan). Jakarta: PT RajaGrafindo Persada.

Kasmir. (2007). Manajemen Perbankan. Jakarta: PT Raja Grafindo Persada.

Otoritas Jasa Keuangan (2017, Oktober 27). SP 102/DHMS/OJK/X/2017 Siaran Pers Market Share Keuangan Syariah Capai 8 Persen. Retrieved Oktober 28, 2018, from www.ojk.go.id.

Otoritas Jasa Keuangan. Statistik Perbankan Syariah Agustus 2018.
Retrieved Oktober 28, 2018, from www.ojk.go.id.

Natalia, E., AR, M. D., \& Rahayu, S. M. (2014). Pengaruh Tingkat Bagi Hasil Deposito Bank Syariah Dan Suku Bunga Deposito Bank Umum Terhadap Jumlah Simpanan Deposito Mudharabah (Studi Pada Bank Syariah Mandiri Periode 2009-2012). Jurnal Administrasi Bisnis (JABI), 9(1), 1-7.

Prasetya, B., Tan, S., \& Delis, A. (2015). Faktor Faktor Yang Mempengaruhi Penghimpunan Dana Pihak Ketiga Perbankan Syariah di Indonesia. Jurnal Perspektif Pembiayaan dan Pembangunan Daerah, 3(2), 92100.

Rosana, W. (2009 ). Perbedaan Persepsi Konsumen Laki-Laki Dan Perempuan Terhadap Daya Tarik Fisik Dan Komunikasi Interpersonal Pada Sales Asuransi . Skripsi .

Undang Undang Republik Indonesia No 21 Tahun 2008 Tentang Perbankan Syariah.

Widayu, H., Nasution, S. D., Silalahi, N., \& Mesran. (2017). Data Mining Untuk Memprediksi Jenis Transaksi Nasabah Pada Koperasi Simpan Pinjam Dengan Algoritma C4.5. Media Informatika Budidarma, 32-37. 